Flooding in the Middle Koyukuk River Basin, Alaska August 1994

\author{
By David F. Meyer
}

U.S. GEOLOGICAL SURVEY

Water-Resources Investigations Report 95-4118

Prepared in cooperation with the

FEDERAL EMERGENCY MANAGEMENT AGENCY

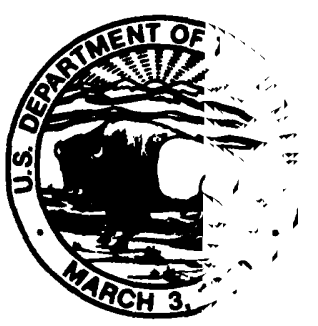

Anchorage, Alaska

1995 


\section{U.S. DEPARTMENT OF THE INTERIOR BRUCE BABBITT, Secretary}

U.S. GEOLOGICAL SURVEY

Gordon P. Eaton, Director

For additional information write to:

District Chief

U.S. Geological Survey 4230 University Drive, Suite 201 Anchorage, AK 99508-4664
Copies of this report may be purchased from:

U.S. Geological Survey

Earth Science Information Center

Open-File Reports Section

Box 25286, MS 517

Federal Center

Denver, CO 80225-0425 


\section{CONTENTS}

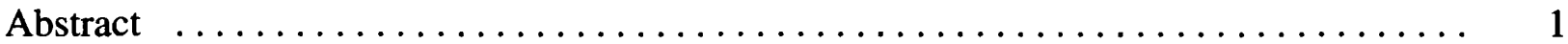

Introduction $\ldots \ldots \ldots \ldots \ldots \ldots \ldots \ldots \ldots \ldots \ldots \ldots \ldots \ldots \ldots \ldots \ldots \ldots \ldots \ldots$

Background $\ldots \ldots \ldots \ldots \ldots \ldots \ldots \ldots \ldots \ldots \ldots \ldots \ldots \ldots \ldots \ldots \ldots \ldots \ldots$

Flood history $\ldots \ldots \ldots \ldots \ldots \ldots \ldots \ldots \ldots \ldots \ldots \ldots \ldots \ldots \ldots \ldots \ldots$

Flood plain management $\ldots \ldots \ldots \ldots \ldots \ldots \ldots \ldots \ldots \ldots \ldots \ldots \ldots \ldots \ldots$

Precipitation in August $1994 \ldots \ldots \ldots \ldots \ldots \ldots \ldots \ldots \ldots \ldots \ldots \ldots \ldots$

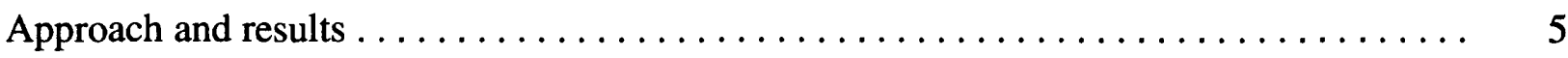

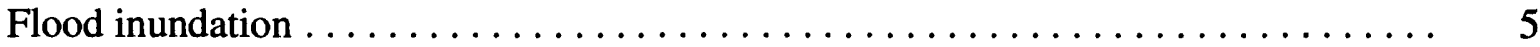

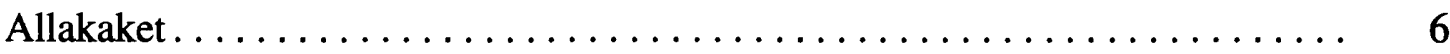

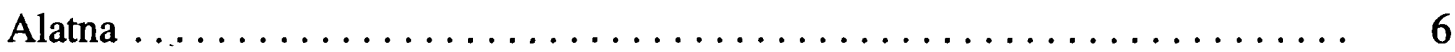

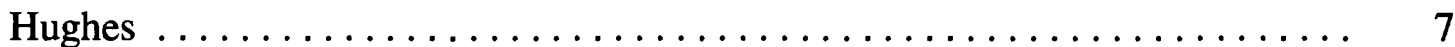

Flood flow and flood flow frequency $\ldots \ldots \ldots \ldots \ldots \ldots \ldots \ldots \ldots \ldots$

References cited $\ldots \ldots \ldots \ldots \ldots \ldots \ldots \ldots \ldots \ldots \ldots \ldots \ldots \ldots \ldots$

\section{PLATES}

1. Flood map of Allakaket and Alatna, Alaska, August 1994 flood

2. Flood map of Hughes, Alaska, August 1994 flood

\section{FIGURES}

1. Map showing location of the Koyukuk River in Alaska. . . . . . . . . . . . . 2

2. Hydrograph showing stage of the Koyukuk River at Allakaket during August 1994.

\section{CONVERSION FACTORS AND VERTICAL DATUM}

\begin{tabular}{rcll}
\hline Multiply & By & To obtaln \\
\hline inch (in.) & 25.4 & millimeter \\
foot (ft) & 0.3048 & meter \\
mile (mi) & 1.609 & kilometer \\
square mile ( $\left.\mathrm{mi}^{2}\right)$ & 2.590 & square kilometer \\
acre-foot (acre-ft) & 1,233 & cubic meter \\
cubic foot per second ( $\left.\mathrm{ft}^{3} / \mathrm{s}\right)$ & 0.02832 & cubic meter per second
\end{tabular}

\section{Sea level:}

In this report "sea level" refers to the National Geodetic Vertical Datum of 1929--a geodetic datum derived f-om a general adjustment of the first-order level nets of both the United States and Canada, formerly called Sea Leve' Datum of 1929. 


\title{
Flooding in the Middle Koyukuk River Basin, Alask August 1994
}

\author{
By David F. Meyer
}

\begin{abstract}
During August 1994, a flood on the Koyukuk River, Alaska, inundated the villages of A llakaket and Alatna and parts of Hughes. Topographic maps of the inundated areas, showing peak watersurface elevations and depths of water, indicate that flooding ranged from 2 to more than 10 feet deep in Allakaket, from 8 to more than 10 feet deep in Alatna, and from 0 to more than 10 feet deep in Hughes. Severe damage to buildings occurred in Allakaket and Alatna; minor damage occurred in Hughes, although some homes were irreparably damaged by inundation. Between the mc nth of the Kanuti River, about 10 miles downstream from Allakaket, to Hughes, the peak dischar $\varepsilon^{\circ}$ was about 330,000 cubic feet per second. A flow of that magnitude at Hughes has an annual probability of occurrence of 1 percent.
\end{abstract}

\section{INTRODUCTION}

Heavy rains during August 15-18 and August 23-27, 1994, in northwest and interior Alaska caused severe flooding in several large basins, and forced the evacuation of three villages along the Koyukuk River: Allakaket, Alatna, and Hughes (fig. 1). On August 26, Governor Hickel de -lared a State Disaster in response to ongoing and predicted floods. Residents of Allakaket and Alatna were evacuated by Army National Guard helicopters on August 28 and those of Hughes was evacuated on August 31. President Clinton declared a National Disaster on September 13, mobilizing the Federal Emergency Management Agency.

Almost 100 homes received damage from the flood in the villages and 38 were completely destroyed (Alaska Department of Emergency Services, written commun., 1994). Many Jomes floated off their foundations in Allakaket and Alatna; some of these homes survived the relonation intact, and have since been releveled and reoccupied, but most were destroyed. More than 307 people were displaced from their homes by flooding. About $\$ 15$ million worth of damage resulted from the floods, about $\$ 10$ million of which occurred in Allakaket, Alatna, and Hughes (Tom Duncan, Federal Emergency Management Agency, oral commun., 1995). Total costs resulting from the floods, including evacuation, temporary housing, and mitigation, as well as damages, are expected to exceed $\$ 70$ million.

The Federal Emergency Management Agency (FEMA) requested the U.S. Geological Survey (USGS) to identify high-water marks resulting from the flooding at Allakaket, Alatna, and Hughes; to prepare maps of the areas inundated on base-topographic maps prepared by Ae"omap U.S., Inc., from September 1994 aerial photography; and to determine the peak water discharge and its estimated recurrence interval. The purpose of this report is to present the information requested by FEMA. 


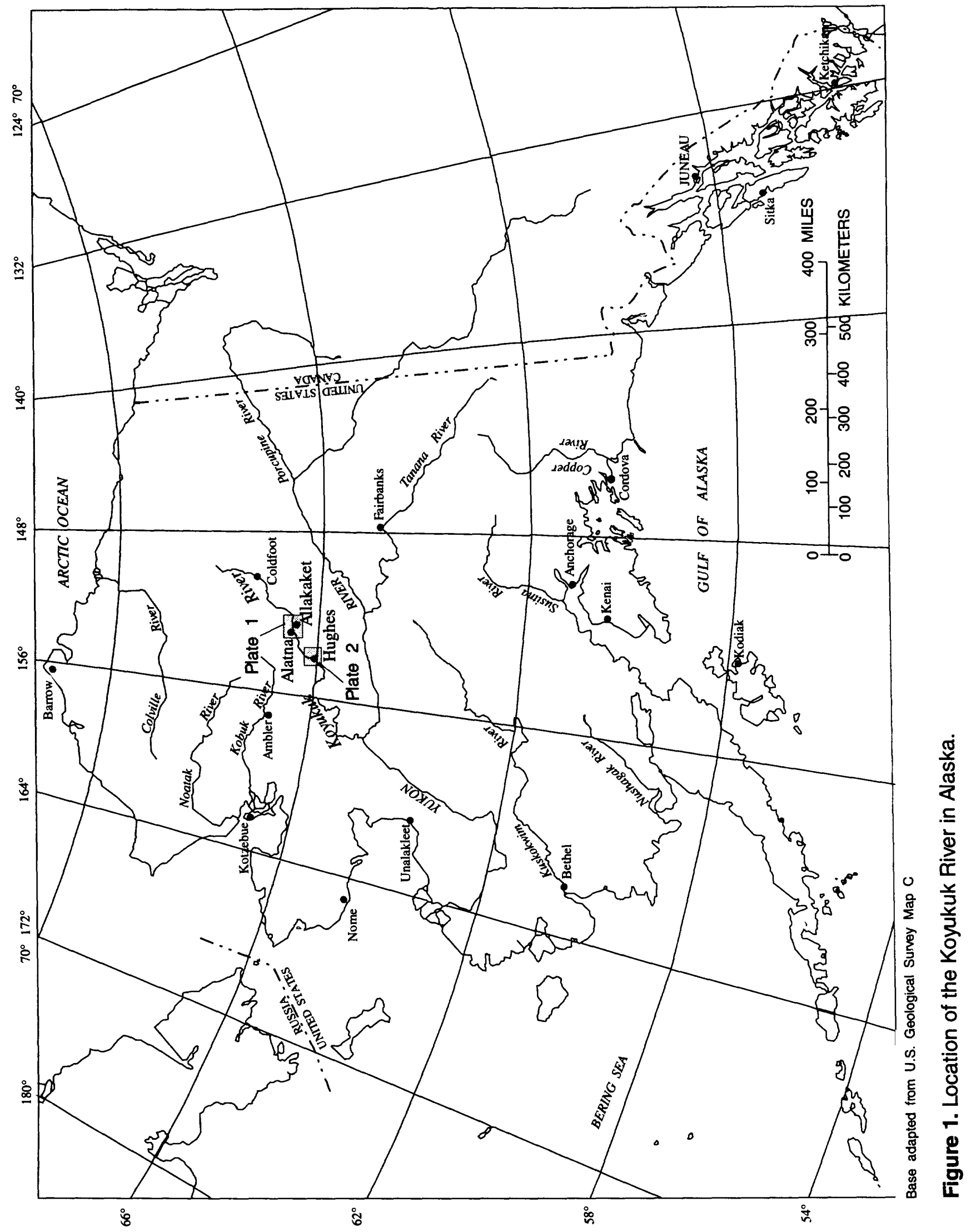




\section{BACKGROUND}

\section{Flood History}

Floods in the interior of Alaska generally are the result of one of three processes: (1) rainfall, usually occurring during the late summer, such as the flood of August 1994; (2) snowmelt, usually occurring during late spring, such as a flood in June 1964; and (3) ice jams, usually occurring during mid to late spring. Rainfall and snowmelt floods are meteorologically generated, whereas icejam floods are hydraulically generated. Ice jams occur at channel constrictions, bridges, san Ibars, or other obstructions to flow, and flooding results from backwater behind blocks of river ice. The velocity of the water is usually low, except when ice jams break. Ice jams are usually accomfanied by rising discharge in the spring, but they are not directly caused by increased flow, and are therefore difficult to predict. The Koyukuk River experiences all three types of flooding. At Hughes, ice jams have been responsible for floods higher than the highest meteorologically generated floxds at least three times since 1964 (Paul Meyer, National Weather Service, written commun., 1994).

At Hughes, the Koyukuk River has a drainage area of $18,360 \mathrm{mi}^{2}$. A USGS stream-gaging station was operated at Hughes from June 1960 to 1982. During that period, the largest flow recorded was $266,000 \mathrm{ft}^{3} / \mathrm{s}$ on June 6, 1964 (U.S. Geological Survey, 1983). In 1961, reside.nts of Hughes reported that a flood in August 1937 reached about the same elevation as the August 1994 flood.

The National Weather Service has operated a flood-warning gage (river stage only) at Allakaket since July 1969. Prior to that time, residents recall two serious floods: a flood in the early 1950's that occurred during August, and a flood sometime during 1966. A flood during August $19 \varepsilon^{?}$ ? had a peak-stage elevation of about $489.8 \mathrm{ft}$, map datum $(27.3 \mathrm{ft}$ National Weather Service gage datum), $8.6 \mathrm{ft}$ below the peak stage of the 1994 flood.

\section{Flood-Plain Management}

In addition to providing emergency relief to disaster victims when a national disaster is declared, FEMA is also mandated to provide cost-effective, long-term hazard mitigation to minimize damage should a disaster recur. In the case of flooding, this can consist of a detailed floodhazard information report, if a Flood Insurance Study has not already been done. These re norts, either detailed flood-hazard information reports or Flood Insurance Studies, commonly entail calculating the flow having a 1 percent annual probability of occurrence and then using one-dimensional steady-state hydraulic models to determine the areas that would be inundated by that flow. Detailed representations of the local topography and hydraulics are generally needed to properly apply the models. However, collecting these types of data can be expensive. No formal Flood Insurance Studies have been completed for the Koyukuk River (U.S. Army Corps of Engineers, 1993).

In the case of the August 1994 floods on the Koyukuk River, an alternative approach was warranted. On the basis of the magnitude and approximate frequency of the type of flooding of August 1994, the USGS, in consultation with FEMA, the Alaska Department of Emergenc.' Services, and the Alaska Department of Community and Regional Affairs decided to: (1) Provide detailed mapping of the water-surface profile and the areas inundated by the flood in and around 
the villages of Allakaket, Alatna, and Hughes. This mapping would be a more accurate indication of areas at risk from probable future flooding than would be a detailed hydraulic model of hypothetical flows based on the calculated 100-year flood. (2) Measure and assign a recurrence interval to the flood in order to qualify the risk associated with a hypothetical 100-year flood. Fortuitously, when this measurement was completed and the flood frequency was determined, the August 1994 flood had a recurrence interval of 100 years at Hughes.

Many small villages in Alaska are not prepared for 100-year floods. At Allakaket and Alatna, a local ordinance required all new building to be built with first-floor elevations above the flood of record. However, the only site-specific flood information available prior to August 1994 was the identification of the peak stage from a flood that occurred in 1989 (U.S. Army Corps of Engineers, 1993). Several larger floods were known to have occurred before the National Weather Service gage was established in 1969, but accurate measurements of their stage were not available.

\section{Precipitation in August 1994}

During the first storm in mid-August, between 1.9 and 4.9 in. of rain was measured in the Koyukuk River basin; the estimated average rainfall in the basin upstream from Allakaket was between 4 and 5 in. (Paul Meyer, National Weather Service, written commun., 1994). Ares ${ }^{\circ}$ to the west and north also received heavy rainfall: 2.8 in. of rain was measured in Kotzebue, on the west coast, over a 6-day period; 1.4 to 3.2 in. of rain was measured in the Noatak River basin during August 15-18; and 2.3 to 3.3 in. of rain was measured in the Kobuk River basin during the same period. The storm produced the highest flows of the past decade in several small rivers in the area and caused many larger rivers to overtop their banks. Minor flooding occurred along the Noatak and Kobuk Rivers, but most damage was caused by ongoing bank erosion that was accelerated by the flood (Paul Meyer, National Weather Service, oral commun., 1995). The Koyukuk Piver at Allakaket rose more than $10 \mathrm{ft}$ in response to the first storm (fig. 2), flooding the gravel airst ip west of town. No damage resulted from the first storm along the middle or lower Koyukuk River.

The second storm, at the end of August, followed a path south of the first storm. Along the coast, the highest rainfall amounts were measured at Unalakleet, $200 \mathrm{mi}$ south of Kotzetne, and less than an inch of rain was measured at Ambler in the Kobuk River basin. About the same amount of rain fell in the Koyukuk River basin during both the first and the second storms. At the Coldfoot precipitation gage - the highest in the Koyukuk River basin- 5.5 in. of rain was measured, and lesser amounts were measured at lower elevations. The drainage basin upstream from Allakaket received rain averaging between 4.5 and 5 in. between August 23-27 (Paul Meyer, National Weather Service, written commun., 1994), about the same amount of rainfall that occurred during the first storm. However, soils were already saturated from the storm of the previous week, so runoff was greater. River stages were already at or above bankfull, and the additional runoff caused flooding throughout the Koyukuk River Basin. 


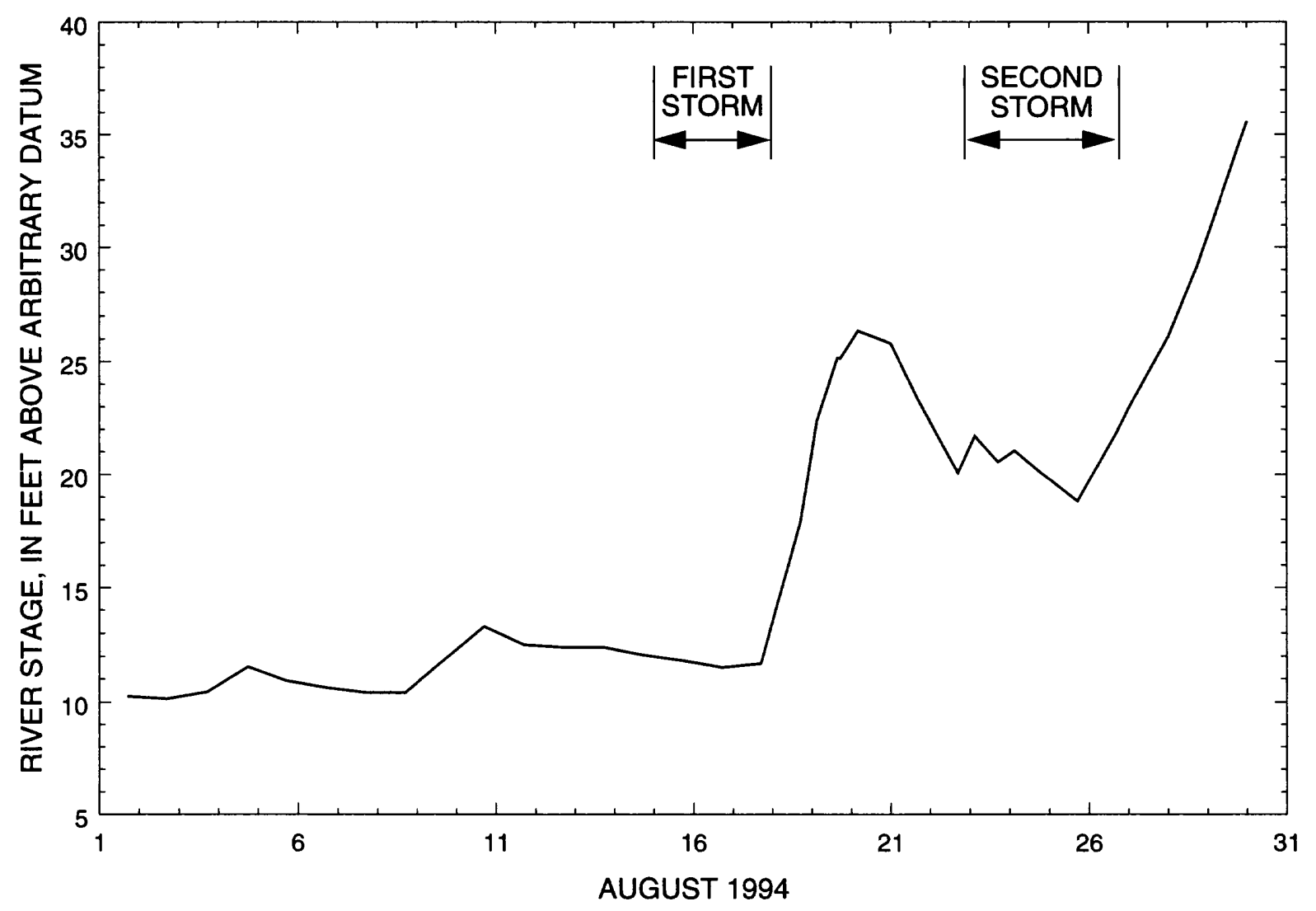

Figure 2. Stage of the Koyukuk River at Allakaket during August 1994

(Paul Meyer, National Weather Service, written commun., 1994).

\section{APPROACH AND RESULTS}

\section{Flood Inundation}

To accomplish the first task (detailed mapping), high-water marks were located in and around the villages, marked on aerial photographs, and surveyed. In most cases, the surveys were done in conjunction with photogrammetric control surveys by FPE Roen Engineers under contrac ${ }^{+}$with Aeromap U.S., Inc. These surveys were referenced to a local assumed vertical datum. At Allakaket, surveys were referenced to a local assumed datum placed by Alaska Department of Transportation and Public Facilities (ADOT/PF). The elevation assumed for this datum is between $5 ?$ and $100 \mathrm{ft}$ above that used for making the USGS topographic map of the area (Bettles, C-6, 1: $\in 3,360$ scale). At Hughes, surveys were referenced to ADOT/PF VA benchmark "Cemetery" (Peter Schnaars, FPE Roen Engineers, oral commun., 1995). The high-water marks were located on a 1:4,800 scale topographic map of Allakaket and Alatna, and on a 1:2,400 scale topographir map of Hughes, both prepared by Aeromap U.S., Inc. using post-flood aerial photographs under contract with FEMA. Water-surface profiles were drawn on the maps. These maps are accurate vertically within $( \pm$ ) one-half contour interval ( $\pm 1 \mathrm{ft}$ everywhere except the southeast corner of the 
Allakaket map, plate 1). The depth of inundation by the flood was determined by subtracting the local topography from the elevation of the water-surface profile, and those data were contc ired to produce a map of water depths experienced during the peak stage of the August 1994 floots. The accuracy of these data is dependent on the accuracy of the topographic map, the accuracy of the high-water marks, and the variability of the water surface profile. The accuracy is believed to be $\pm 2 \mathrm{ft}$ where the high-water profile is interpolated between observed high-water marks, and $\pm 4 \mathrm{ft}$ where it is extrapolated (on the eastern part of Allakaket, plate 1).

Maps of the depths of inundation by the August 1994 flood (plates 1 and 2) indic re that Alatna and parts of Allakaket were flooded to depths greater than $6 \mathrm{ft}$, and most of Hughes and other parts of Allakaket were flooded to depths of 2 to $6 \mathrm{ft}$.

\section{Allakaket}

Virtually all of Allakaket was flooded (plate 1). Only a few houses built on piles and one house south of town built on a gravel pad were not damaged by inundation of at least the subfloor. Flood depth in the northern, older section of town along the riverbank ranged from 6 to more than $10 \mathrm{ft}$. Log buildings in this area that were not anchored to their foundations commonly floated away for distances ranging from a few feet to several miles: one structure was located intact more than 36 mi downstream from Allakaket. The airstrip, on the west side of town, and most of the sloughs and abandoned channels in the area were flooded to depths of $10 \mathrm{ft}$ or more. An area of higher ground is present south of the older part of town, about 2,000 ft south of the river. Newer houses there, referred to locally as the "HUD houses," are built on piles, about $5 \mathrm{ft}$ above gravel pads, which are 1 to $2 \mathrm{ft}$ above the flood plain. Where these houses were built on the highest ground, they were undamaged; where they were built on lower ground, their subfloors and interio's were flooded. The elevation of high-water marks fall from $499 \mathrm{ft}$ (map datum), at the northeast edge of town, to $496 \mathrm{ft}$ (map datum), at the base of the bluff about $1 \mathrm{mi}$ south of town.

Water velocity was great enough to significantly scour and rework the flood plain only in the area of the northern end of the airstrip and the adjacent ball field. Minor scour and sedimert deposition occurred in many places where flow crossed roads and gravel pads, but where the flood plain was protected by vegetation, scour did not occur. Riverbank erosion occurred during the flood, but riverbank erosion is common during seasonal flows, and the erosion that occurred during th $\bullet$ flood was not significantly greater than normal annual erosion rates.

\section{Alatna}

All of Alatna was flooded to depths greater than $8 \mathrm{ft}$ (plate 1) except one house, buil ${ }^{+}$on the valley wall at the north edge of town. Many log structures floated off their foundations, and even two newer "HUD houses," built on piles about $8 \mathrm{ft}$ above the flood plain, were flooded above the floor. Riverbank erosion is an annual process at Alatna, and some riverbank erosion occurred during the flood, but not significantly more than normal. High-water marks were at an elevation of about $497 \mathrm{ft}$ (map datum) in Alatna. 


\section{Hughes}

Most of the center and northern part of Hughes was inundated by 4 to $6 \mathrm{ft}$ of water (plate 2). Some houses built along the riverbank in the northern part of town were built on gravel pads, or otherwise elevated above the surrounding flood plain, and only one house was flooded more than $6 \mathrm{ft}$ deep. The elevation of high-water marks falls from $271 \mathrm{ft}$ (map datum) at the north end of town to $268 \mathrm{ft}$ (map datum) at the south end. Areas flooded to depths greater than $8 \mathrm{ft}$ are either near the river or along swampy sloughs, abandoned channels, or ditches. Many homes and the Community Center in the southeastern part of town are built on ground along a gently sloping part of the valley wall, above the level of the flood.

Flood-related damage was mostly caused by inundation; few structures were moved from their foundations. Hughes is located downstream from a bedrock point on the east bank of the Koyukuk River that constricts the flood plain, and this point protected much of the village from high-water velocities experienced at Allakaket and Alatna. Soils within a few hundred feet of the point are finer than elsewhere on the flood plain, indicating that fine sediment is deposited in a zone of low velocity. Riverbank erosion was negligible during the flood.

\section{Flood Flow And Flood Flow Frequency}

The second task (recurrence interval) was accomplished by making a slope-area indire-t discharge measurement of the peak discharge (Dalrymple and Benson, 1967) at a site on the Koyukuk River between Allakaket and Hughes. An ideal indirect measurement of peak discharge requires a reach of channel (1) where the flow is uniform and contained within well-defined banks, (2) where channel expansions are negligible, and (3) where high-water marks are well defined.

No such site was identified in the middle Koyukuk River basin. A site about 16 mi southwest of Allakaket was identified as being the best site available. The site is located at lat $66^{\circ} 26^{\prime} 38^{\prime \prime} \mathrm{N}$., long $153^{\circ} 06^{\prime} 0^{\prime \prime} \mathrm{W} ., 1.3 \mathrm{mi}$ downstream from Klaluthyiit Bluff, $3.3 \mathrm{mi}$ downstream from the mouth of Kanuti River, $15.5 \mathrm{mi}$ southwest of Allakaket, and $42.5 \mathrm{mi}$ northeast of Hughes (fig. 1). The drainage area upstream from this site is $17,350 \mathrm{mi}^{2}$. At this site, overbank flooding was minimalaccounting for less than 1 percent of the flow-and extended about $200 \mathrm{ft}$ from the left bank of the main channel. Most other reaches of the middle Koyukuk River experienced extensive overbank flooding, extending as much as $2 \mathrm{mi}$ from the banks of the main channel. The slope-area measurement indicated that the peak discharge at the measurement site was $331,000 \mathrm{ft}^{3} / \mathrm{s}$.

Independent of the slope-area measurement, a peak discharge was computed at the streamgaging station at Hughes, using the following: surveyed high-water marks, a discharge measurement made on September 7, 1994, and the stage-discharge rating curves developed during the period the gaging station was in operation. This computation indicated that the peak discharge at Hughes was about $330,000 \mathrm{ft}^{3} / \mathrm{s}$, which was nearly the same as that measured at the slope-area site.

The drainage area increases from $17,350 \mathrm{mi}^{2}$ at the indirect-measurement site to $18,360 \mathrm{mi}^{2}$ at Hughes, an increase of 6 percent. Most of the additional drainage area is lowlands, and rinfall was minimal during the period of flooding in Allakaket, Alatna, and Hughes. Neither of th ${ }^{\circ}$ discharge measurements are accurate enough to determine whether there was a significant increase in flow as a result of the additional area, or if the flood peak was attenuated along the more th an 40 river miles between the indirect-measurement site and the gaging station. 
After the peak discharge was computed, the record of annual peak flows measured at Hughes was updated, treating the August 1994 peak as a historic peak (i.e. outside the systematic record) and assuming that no flow was larger since 1937. Then, the 100-year discharge was recc mputed using standard methods for determining flood-flow frequency (Interagency Advisory Committee on Water Data, 1982). These computations indicated that the 100-year discharge at the stream-gaging station at Hughes is $332,000 \mathrm{ft}^{3} / \mathrm{s}$, with 95 percent confidence limits of $262,000 \mathrm{ft}^{3} / \mathrm{s}$ (lower) and $481,000 \mathrm{ft}^{3} / \mathrm{s}$ (upper).

Loon Lake is a landslide-dammed lake in the headwaters of the John River, a tributary to the Koyukuk River, about 80 mi northwest of Coldfoot (fig. 1). The lake, which has a surface area of about $0.3 \mathrm{mi}^{2}$, was reported to have drained between 20 and $40 \mathrm{ft}$ during the week surrounding the flood peak. There were no witnesses to the event, and too little information exists regarling the history of the lake or the nature of the landslide dam to speculate as to the possible failure mechanisms. Loon Lake could have contributed between 4,000 and 8,000 acre-ft of water to the reak, but the timing of the release is unknown, and the reports are secondhand. The sudden releas? of this much water could have had significant effects just downstream from Loon Lake, but the resulting flood wave would have attenuated rapidly and probably had no effect on the peak discharge of the Koyukuk River.

\section{REFERENCES CITED}

Dalrymple, Tate, and Benson, M.A., 1967, Measurement of peak discharge by the slope-area method: U.S. Geological Survey Techniques of Water Resources Investigations, book 3, chap. A2, 12 p.

Interagency Advisory Committee on Water Data, 1982, Guidelines for determining flood flow frequency: U.S. Geological Survey, Hydrology Subcommittee Bulletin 17B.

U.S. Army Corps of Engineers, 1993, Alaskan communities flood hazard data: Anchorage, Alaska, 335 p.

U.S. Geological Survey, 1983, Water resources data, Alaska-Water year 1982: U.S. Geological Survey V'ater-Data Report AK-82-1, 363 p. 